\title{
Review of Application of Fiber Reinforced Polymer (FRP) in Structural Engineering
}

\author{
Reshed Raad Jawad AL-Rebaye \\ University Of Sumer \\ Dhe-Qar, Iraq
}

\begin{abstract}
Fiber-reinforced polymer (FRP) materials have emerged as an alternative material for producing reinforcing bars for concrete structures. FRP reinforcing bars offer advantages over steel reinforcement in that FRP bars are noncorrosive, and some FRP bars are nonconductive. The professional using this technology should exercise judgment as to the appropriate application of FRP reinforcement and be aware of its limitations as discussed. Currently, areas where there is limited knowledge of the performance of FRP reinforcement include fire resistance, durability in outdoor or severe exposure conditions, bond fatigue, and bond lengths for lap splices. Further research is needed to provide additional information in these areas.
\end{abstract}

Keywords: aramid fibers; carbon fibers; development length; fiber-reinforced polymers

\section{INTRODUCTION}

A structural reinforcing bar made from filaments or fibers held in a polymeric resin matrix binder. The FRP Bar can be made from various types of fibers such as Glass (GFRP) or Carbon (CFRP). FRP bars have a surface treatment that facilitates a bond between the finished bar and the structural element into which they are placed.

During the last two decades, fiber reinforced polymer (FRP) materials have been used in a variety of configurations as an alternative reinforcement for new and strengthening civil engineering structures and bridges. The attractiveness of the material lies mainly in their high corrosion resistance, high strength and fatigue resistance. In some cases, the nonmagnetic characteristics became more important for some special structures .

\section{APPLICATION OF FRP}

An important application of FRP, which is becoming more popular (Tan, 2003), used of FRP as reinforcement in concrete structures. The use of the FRPs in concrete structures include: (a) the internal reinforcing (rod or bar) which will be used instead of the steel wire (rod) equivalent; and (b) the external bonded reinforcement, which is typically used to repair/strengthen the structure by plating or wrapping FRP tape, sheet or fabric around the member.

There are fundamental differences between the steel and FRP reinforcements: the latter has a lower modulus of elasticity, The modulus of elasticity for commercially available glass and aramid FRP bars is 20 to $25 \%$ that of steel compared to 60 to $75 \%$ for carbon FRP bars and linear stress-strain diagram up to rupture with no discernible yield point and different bond strength according to the type of FRP product. These characteristics affect the shear capacity of FRP reinforced concrete members. Due to the relatively low modulus of elasticity of FRP bars, concrete members reinforced longitudinally with FRP bars experience reduced shear strength compared to the shear strength of those reinforced with the same amounts of steel reinforcement. This fact is supported by the findings from the experimental investigations on concrete beams without stirrups and reinforced longitudinally with carbon and glass FRP bars (ElSayed et al. 2004, 2005b).

El-Sayed et al. 2005, they carried out an experimental study to investigate the shear strength of concrete beams without shear reinforcement (stirrups) and reinforced in the longitudinal direction with different types and ratios of FRP bars. They found that the ratio of concrete shear strength of concrete beams reinforced with FRP bars to that of beams reinforced with steel is proportional to the cube root of the axial stiffness ratio between FRP and steel reinforcing bars. Based on the experimental study a proposed equation was presented to calculate the shear strength of concrete beams reinforced with FRP bars.

F.M. Wegian, H.A. Abdalla, presented an experimental investigation on the behavior of concrete beams reinforced with different FRP bars. Three beams were reinforced by GFRP, Isorod, two beams were reinforced by GFRP, C-bar, and two beams were reinforced by CFRP, Leadline. The ultimate behavior of the seven simply supported FRP reinforced concrete beams was used to evaluate their flexural and shear capacities. Based on the experimental results of this investigation a simplified expression for the shear capacity of FRP reinforced concrete beams is proposed. The analytical proposed method was also substantiated by test results available in the literature for beams reinforced with FRP bars. Good agreement was shown between the theoretical and the experimental results.

Z. Omeman et al. 2008, investigation the shear strength, deflection, and mode of failure of concrete short beams reinforced with CFRP bars and compared with that of similar beams reinforced with steel bars. The experimental study showed that using CFRP bars as tensile reinforcement in RC 
short beams had a significant effect on the shear strength and deflection of tested beams.

\section{CONCLUSION}

From this review we can concluded that using of FRP in many space of civil engineering. We can used as mail reinforced bars in concrete beam and used for stirrup but the bent must be in factory. Also can used for strengthen of concrete

\section{REFERENCES}

[1] A.K. El-Sayed et al. 2005. Shear Strength of Concrete Beams Reinforced with FRP Bars: Design Method.

[2] P. Valerio, T.J. Ibell and A.P. Darby. 2002. Shear Assessment and Strengthening of Contiguous-Beam Concrete Bridges Using FRP Bars.

[3] Y.X. Zhang, Y. Zhu . 2010. A new shear-flexible FRPreinforced concrete slab element", "Composite Structures.

[4] F.M. Wegian, H.A. Abdalla. 2005. Shear capacity of concrete beams reinforced with fiber reinforced polymers"," Composite Structures.

[5] E. Vintzileou, E. Panagiotidou. 2007. An empirical model for predicting the mechanical properties of FRPconfined concrete. Construction and Building Materials.

[6] Hayder A. Rasheed, Rim Nayal, Hani Melhem. 2004. Response prediction of concrete beams reinforced with FRP bars. Composite Structures. structure as sheet in the surface of beam, slab and column.FRP weak for fire because it have TP degree and it must be protected from fire with suitable concrete cover.

[7] E. F. EL-SALAKAWY and B. BENMOKRANE2004.. Concrete deck bridge slabs reinforced with FRP . Emirates Journal for Engineering Research.

[8] Luciano Ombres et al. 2000. flexural analysis of one way slab reinforced with GFRP rebar.

[9] W.K. Feeser and V.L. Brown. 2004.Guide Examples for Design of Concrete Reinforced with FRP Bars.

[10] Ehab El-Salakawy et al . 2005 .Field Investigation on the First Bridge Deck Slab Reinforced with Glass FRP Bars Constructed in Canada. ASCE.

[11] Sherif El-Gamal et al . 2007. Influence of Reinforcement on the Behavior of Concrete Bridge Deck Slabs Reinforced with FRP Bars. ASCE.

[12] M. Dawood , E. Taylor, S. Rizkalla. 2010.Two-way bending behavior of 3-D GFRP sandwich panels with through-thickness fiber insertions. Composite Structures.

[13] Yefei Wu et al: 2010 " On shear bond strength of FRPconcrete structures", "Engineering Structures .

[14] K. SUNGJOONG .2007 . Behavior of High-Strength Concrete Columns. PhD thesis, USA. 